The Journal of SPORT, 2015, 4(1), 19-46 @ Kent State University

\title{
Shaping Policy and Practice in Intercollegiate Athletics: A Study of Student Perceptions of Resource Allocation for Athletics and its Effect on Affordability of Higher Education.
}

\author{
B. David Ridpath
}

Ohio University

Jeff Smith

University of South Carolina Upstate

Daniel Garrett

Center for College Affordability and Productivity

\section{Jonathan Robe}

Center for College Affordability and Productivity

\begin{abstract}
Intercollegiate athletics is an increasingly expensive venture in American higher education. Noted athletic powers have budgets exceeding \$100 million, and schools with lesser reputations increase athletic budgets despite lacking the ability to generate large sums of revenue through ticket sales and other sources. Higher education is faced with declining amounts of non-student support for academic and non-academic programs (Vedder \& Denhart, 2010). Public institutions increasingly rely on funds provided by institutional subsidies and student activity fees (Vedder \& Denhart, 2010; Chapman, Ridpath, \& Denhart, 2014). This mixed-methods study addresses, using Asymmetrical Information Theory (Akerlof, 1970), student perceptions of student activity fees. The population is represented by students $(n=3,282)$ enrolled during the 2012-13 academic year at institutions in the Mid-American Conference (MAC). Findings suggest students are aware of the fees, but not aware of the amount or purpose. Many expressed concern about transparency and affordability of education because of the amount of subsidies to fund athletic programs.
\end{abstract}


Higher education access and affordability has become the focus of policymakers as costs have climbed in recent years. The attainment of a college degree is often considered paramount to achieving gainful employment, and earning much more over a lifetime than one otherwise would (NCPSI, 1998). In recent years, the funding of institutions of higher learning has been discussed on a more frequent basis (McClendon, Hearn, \& Mokher, 2009; Tandberg, 2010a, 2010b). Budget cuts are occurring on campuses throughout the United States despite the rising costs associated with attending college (U.S. Department of Education, 2010). That has sparked many discussions as to how universities can maintain academic standing and primacy without placing a large financial burden on students.

The long-standing debate over college costs and access to higher education by the American population without regard to race, sex, or socioeconomic background has reached a crescendo in American political rhetoric. President Barack Obama spoke about rising tuition costs during his 2012 State of the Union address and put colleges and universities "on notice" by stating in 2012 that federal funding for higher education would decrease if tuition continued to rise (Thomas, 2012). For the past 25 years, tuition and fees have increased greatly, growing in 2012 to $5.6 \%$ beyond the rate of inflation (Page, 2011). General student fees at public institutions are rising even quicker at a rate of $13 \%$ or higher over a similar time frame (Vedder \& Denhart, 2010).

While state governments have discussed limiting tuition increases, little focus has been placed on the additional fees that students must pay in addition or as part of their tuition. Although there have been some notable studies on this subject including Chapman, Ridpath and Denhart (2014), Ott (2009), Kent State University (2011), Smith and Caldwell (2013), and Vedder \& Denhart (2010). This topic should be examined further, given the increased focus on higher education costs and the inability of many to pursue a college degree in the current unstable world economic climate (Vedder \& Denhart, 2010). One such discussion revolves around athletic department fee subsidies students must pay as part of tuition and general fees to attend.

\section{Institutional Subsidies for Intercollegiate Athletics \\ Literature Review}

The often prevailing notion that athletic departments operate self-sufficiently like other campus auxiliaries such as housing and dining services remains widespread (Weaver, 2011). However, according to a 2010 USA Today study of the then-119 NCAA Division I-A schools, on average, $60 \%$ of athletic department income came from student fees and institutional subsidies. That represented an increase of over $20 \%$ on average over four years. In 2011-12, subsidies for all of Division I athletics rose another $10 \%$ by nearly \$200 million compared to 2010-11, reaching a total of \$2.3 billion. (Berkowitz, 2013; Berkowitz, Upton, \& Brady, 2013; Berkowitz, Upton, McCarthy, \& Gillum, 2010; Weaver, 2011). University athletics subsidization takes three forms: (1) Direct subsidy 
from a general fund; (2) Indirect facility and administrative support, and; (3) mandatory fees students pay as a part of their tuition and fee bill (Chapman et al., 2014).

Student general fees, separate from course related and laboratory fees, are generally considered a revenue source to fund extracurricular activities that students desire (Denhart \& Ridpath, 2011). In choosing a university to attend, high-school students consider many factors and place emphasis on university perception ("The Image of Ohio University,” 2007). Such factors include the price differential of two specific universities (Bergerson, 2009), the academic programs/majors offered, social activities, and extra-curricular activities, among others. As athletic fees continue to rise, more research is needed into whether the importance universities place on athletics coincides with the importance students place on athletics, specifically with regard to college choice, affordability, willingness to pay and knowledge of these fees.

\section{How Public Institutions of Higher Learning Expend Budget Dollars}

Funding sources for public four-year institutions vary; according to the National Center for Education Statistics, the main sources include tuition and fees, federal and state grants and contracts, sales and services of auxiliary enterprises, independent operations, and state and local appropriations (Chapman et al., 2014; U.S. Department of Education, 2010). The general fee generates revenue for various activities that provide a better college experience for the student population, but receive little-to-no money through tuition.

Universities struggled throughout the 1800s to raise money for providing higher education to students with academic potential (Rudolph, 1962). Initially, due to benevolence and Christian beliefs foundational to the creation of American colleges, administrations felt it necessary to put student needs above tuition collection. DePauw University tried to skirt problems imposed by free tuition; in 1873, they gave all students free tuition, and charged mandatory fees (Rudolph, 1962). However, it wasn't until the early 1900s when the idea of student fees took a firm hold. Students began collecting voluntary student fees to provide a well-rounded experience in activities beyond the classroom for all students (Chapman, et al., 2014; Lorence, 2003). Those fees met a certain level of scorn as students felt they funded activities tangential to the aims of institutions of higher learning. After World War I, institutions of higher learning were thought to now have the responsibility of building character and well-roundedness as well as providing a comprehensive social and educational experience (Chapman et al., 2014; Rudolph, 1962). It wasn't until the 1960s that student fees again faced controversy. Students began to use student fees to fight for rights and freedoms as campus activism took root (Meabon, Alexander, \& Hunter, 1979).

Public Interest Research Groups (PIRGs) were formed on college campuses across the nation by Ralph Nader during the 1970s. On the basis of advocacy for the benefit of college students, PIRGs staked a claim to a portion of the student fee money (Jaschik, 2007). Other groups followed suit, some considered more controversial than 
PIRGs, such as religious and other political advocacy groups. Students questioned the legality of being forced to pay student fees to support groups with viewpoints that differed from their own, and filed lawsuits for the right to opt out of certain fees (Lorence, 2003). The rising operating costs of a NCAA Division I intercollegiate athletic department, and how it is primarily funded, have also come under scrutiny, but for largely different reasons. Students attending universities often face financial challenges post-college when student loans need to be repaid. Student loan default, huge debt amounts, and repayment challenges for college graduates are just some of the reasons Obama spoke out about rising tuition at American colleges and universities (Thomas, 2012). The total cost of college, including the payment of fees, has increased the level of interest in the growth of this higher education expense (Chapman et al., 2014; Vedder \& Denhart, 2010).

A contributing factor to the closer examination is the growing phenomenon of the intercollegiate athletics "arms race," driven by a consistent justification for the increasing costs of intercollegiate athletics commonly called the "Front Porch Theory." The belief in this theory drives many monetary decisions in college sports as university presidents and trustees view athletics as the window that shapes university perception (Suggs, 2003). If that window is broken or dirty like the front porch of a house, it damages the reputation of other institutional aspects (Chapman, et al., 2014; Denhart \& Ridpath, 2011; Frank, 2004; Litan, Orszag \& Orszag, 2003; Vedder \& Denhart, 2010). Many university presidents and athletic directors often claim, specifically in mid-major conferences like the Mid-American Conference, that students greatly value a strong intercollegiate athletics program as part of their collegiate experience. In addition it is suggested that a successful athletic program significantly influences college choice, fundraising, increases the numbers and quality of applicants, and provide a window to the institution that by extension can enhance research and academic activities (Rate \& Karr, 2011; Suggs, 2003). Supporters also cite connections with alumni, donors, and government officials (“2011-12 Comprehensive Fee Report-Athletic Fee,” 2012; Berkowitz, et al., 2013; Weaver, 2011). However, little empirical research exists to support those assertions. In most situations where there are measurable returns, such as higher application rates and fundraising, it is typically a short-term, unsustainable spike that doesn't create long-term benefits (Chapman, et al., 2014; Denhart \& Ridpath, 2011; Frank, 2004; Litan, et al., 2003; Vedder \& Denhart, 2010).

To keep the front porch in order, institutions often feel compelled to participate in a "winner-take-all market" (Frank \& Cook, 1995). The "winner-take-all market" is an economic theory that suggests institutions face powerful incentives, fueled by the success of direct competitors, to increase expenditures for a competitive edge, even though revenues generated directly by college athletic programs fall far short of covering their costs in the overwhelming majority of cases (Chapman et al., 2014; Frank \& Cook, 1995; Berkowitz, 2010). Since generated revenue fails to cover athletic operating expenses at nearly all institutions, the athletic budget gaps are almost always filled by subsidies from 
other institutional resources and, most substantially, student fees to cover the increased costs and deficit (Vedder \& Denhart, 2010). Discussion often revolves around the morality of university subsidies for athletic departments while state government support for higher education is dwindling (Chapman, et al., 2014; Denhart \& Ridpath, 2011; Smith \& Caldwell, 2013; Vedder \& Denhart, 2010).

Each university and state allocates its student fees differently, but several areas listed below are consistent among public institutions in the United States and allocation to these primary areas has remained virtually unchanged for 60 years (Vedder \& Denhart, 2010). State legislatures provide public colleges and universities guidelines for eight general areas that are permitted to receive funds from student fees, although they vary by state:

- Student health services

- Student social centers

- Debt service on student personnel facility

- Student government or student publications

- Student recreational programs

- Student cultural programs

- Debt service on general social facilities

- Intercollegiate athletics (Chapman et al., 2014; Millet, 1969).

Other areas noted in the survey for this study that student fees fund include club sports, university outreach/community service, and other student groups and organizations.

\section{Student Fees Allocated to Intercollegiate Athletics}

Notably, in the Mid-American Conference (MAC), intercollegiate athletics receive some of the highest funding from student fees (Berkowitz, Upton, McCarthy, \& Gillum, 2010) and is an ideal population to address the theorized research questions and support research-based conclusions due to being one of the highest student fee subsidized athletic conferences. The subsidy has become more much expensive over time as athletic costs have soared at rates beyond growth in generated revenues (Vedder \& Denhart, 2010). Most relevant to this study is the specific "student athletic fees" subsidy. Student athletic fees often provide benefits or at least a perceived quid pro quo for the students. The most common example of a benefit is what is advertised as reduced or free admission to institutional athletic events, even though the cost of admission is paid up front via the fee allocation whether the student attends the games or not (Berkowitz et al., 2010; Chapman, Ridpath, \& Denhart; Denhart \& Ridpath, 2011).

Several major Bowl Championship Series (BCS) institutions such as the University of Texas, The Ohio State University, and the University of Alabama do not charge fees to support their athletic departments and students pay for tickets to attend many athletic events, but others such as the University of Virginia do charge the subsidy, 
while schools like Clemson University are considering it (McGranahan, 2014). Many institutions charge more than $\$ 1,000$ as an athletic subsidy per academic year, including Longwood, Norfolk State, VMI, and William and Mary (Table 1). However, a small sample has been built in other studies to question whether students, parents, and faculty feel athletics are as important as the administration feels they are and worth the amount of subsidy assessed (Berkowitz et al., 2010; Chapman et al., 2014; Vedder \& Denhart, 2010).

It can be debated that inconsistencies exist in the accuracy and transparency of the presentation of student athletic fees within National Collegiate Athletic Association (NCAA) Division I public institutions since the presentation of costs to the consumer is not standardized. Utilizing data from annual athletic department revenue/expense report submissions to the NCAA, specifically the Equity in Athletics Disclosure (EADA) Report, and publically available online information concerning enrollment at those public institutions, athletic subsidies per full-time equivalent (FTE) student can be derived, but it can be challenging to find the exact amounts charged. The subsidy per FTE measure in the EADA report is a total allocation of university resources and is more reflective of the cost of athletics per full-time student. Some institutions, such as the Michigan based institutions in the MAC have their student fees for athletics included in a total tuition amount rather than a separate fee (Vedder \& Denhart, 2010). Coastal Carolina University (CCU) in Conway, South Carolina, states on the university website that student athletic fees (in-state) are \$175 per semester, \$350 annually. In CCU’s 2010-11 filing with the NCAA, they indicated that athletic fee revenues were $\$ 3,720,622$, while "other school funds" utilized to subsidize athletics were $\$ 12,898,882$, for a total subsidy of $\$ 15,619,504$. When contacted about the source of the "other school funds," a university official stated the funds come from tuition, but as stated prior some tuition amounts already include the fee for athletics. At Coastal Carolina, the subsidy from tuition is likely at least \$1,935 annually per FTE, and not the published \$350 (Smith \& Caldwell, 2013). Data compiled for the 227 public Division I institutions revealed that total subsides in the academic year 2010-11 were $\$ 2,178,569,185$, while educating $4,186,050$ FTEs, or $\$ 520$ per student. In many cases this amount was higher than the published student fee costs. The data in Table 2 exhibits the 10 states with the highest total subsidies to athletics within Division I public institutions in 2010-11. 
Table 1

Total of Athletic Subsidies based on FTE/Enrollment 2010-11 (USA Today, 2010)

\begin{tabular}{ccccc}
\hline School & Conference & $\begin{array}{c}\text { Athletic } \\
\text { Subsidies }\end{array}$ & FTEs & FTE \\
\hline Air Force & Mt. West & $\$ 25,736,400$ & 4,619 & $\$ 5,572$ \\
Delaware State & MEAC & $\$ 10,522,067$ & 3,512 & $\$ 2,996$ \\
Citadel & Southern & $\$ 8,394,216$ & 2,832 & $\$ 2,964$ \\
Army & Patriot & $\$ 11,760,014$ & 4,686 & $\$ 2,510$ \\
VMI & Big South & $\$ 3,083,712$ & 1,569 & $\$ 1,965$ \\
Coastal Carolina & Big South & $\$ 15,619,504$ & 8,071 & $\$ 1,935$ \\
South Carolina State & MEAC & $\$ 7,472,312$ & 3,989 & $\$ 1,873$ \\
Winthrop & Big South & $\$ 8,804,646$ & 5,263 & $\$ 1,673$ \\
Norfolk State & MEAC & $\$ 10,063,010$ & 6,081 & $\$ 1,655$ \\
Alabama State & SWAC & $\$ 8,084,904$ & 5,164 & $\$ 1,566$ \\
Longwood & Big South & $\$ 6,633,814$ & 4,302 & $\$ 1,542$ \\
Delaware & CAA & $\$ 28,535,457$ & 19,613 & $\$ 1,455$ \\
Nevada-Las Vegas & Mt. West & $\$ 32,292,436$ & 22,663 & $\$ 1,425$ \\
William \& Mary & CAA & $\$ 10,796,203$ & 7,690 & $\$ 1,404$ \\
Savannah State & Ind. & $\$ 5,221,562$ & 3,738 & $\$ 1,397$ \\
James Madison & CAA & $\$ 25,704,568$ & 18,471 & $\$ 1,392$ \\
Arkansas-Pine Bluff & SWAC & $\$ 4,326,279$ & 3,196 & $\$ 1,354$ \\
New Jersey Tech & Great West & $\$ 9,934,161$ & 7,496 & $\$ 1,325$ \\
New Hampshire & Am East & $\$ 18,348,442$ & 13,946 & $\$ 1,316$ \\
Montana State & Big Sky & $\$ 14,534,373$ & 11,213 & $\$ 1,296$ \\
Alcorn State & SWAC & $\$ 4,160,650$ & 3,247 & $\$ 1,281$ \\
Eastern Michigan & MAC & $\$ 22,764,471$ & 17,828 & $\$ 1,277$ \\
Jacksonville State & Ohio Valley & $\$ 9,721,336$ & 7,616 & $\$ 1,276$ \\
Wyoming & Mt. West & $\$ 13,981,364$ & 11,089 & $\$ 1,261$ \\
South Carolina Upstate & Atlantic Sun & $\$ 5,880,819$ & 4,763 & $\$ 1,235$
\end{tabular}


Table 2

Division I Athletic Subsidies by State, 2010-11

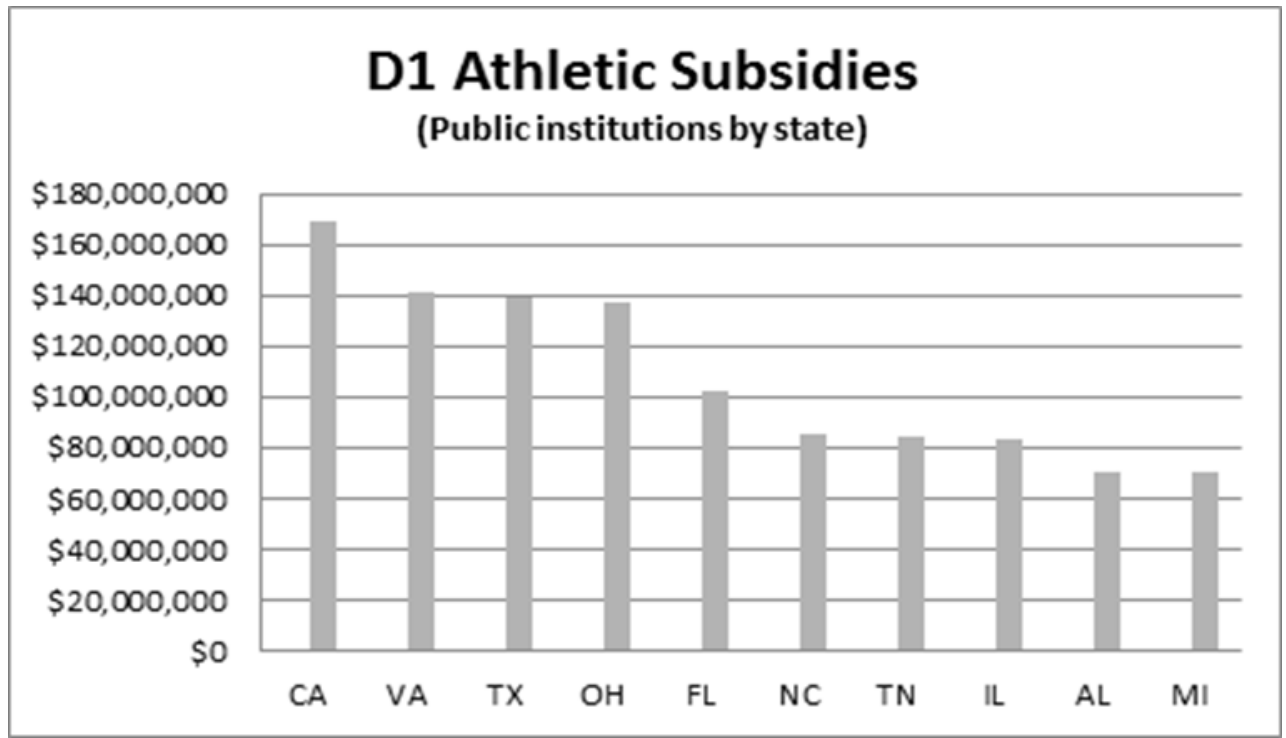

Athletic subsidies have also been called a regressive tax, with the highest athletic subsidies aligning with institutions whose students most rely on Pell Grants and federally subsidized loans (Table 2) (Vedder \& Denhart, 2010). Table 3 demonstrates the disparity between the revenues generated by athletic departments at major conferences (Big Ten, SEC, Big 12, Pac-12, ACC and Big East) and the mid-major conferences, similar to the MAC (Table 4). The average subsidy per student at a public university in a major revenue-generating conference such as the Big Ten Conference (Ohio State and Michigan for example) is $\$ 61$, in contrast to the average subsidy per student in the Big South Conference (University of North Carolina-Asheville, Winthrop, Coastal Carolina, Radford, and Longwood Universities, and Virginia Military Institute) is \$1,512 (Smith \& Caldwell, 2013). 
Table 3

Differences in Per-Student Athletic Subsidy between Conferences, 2010-11

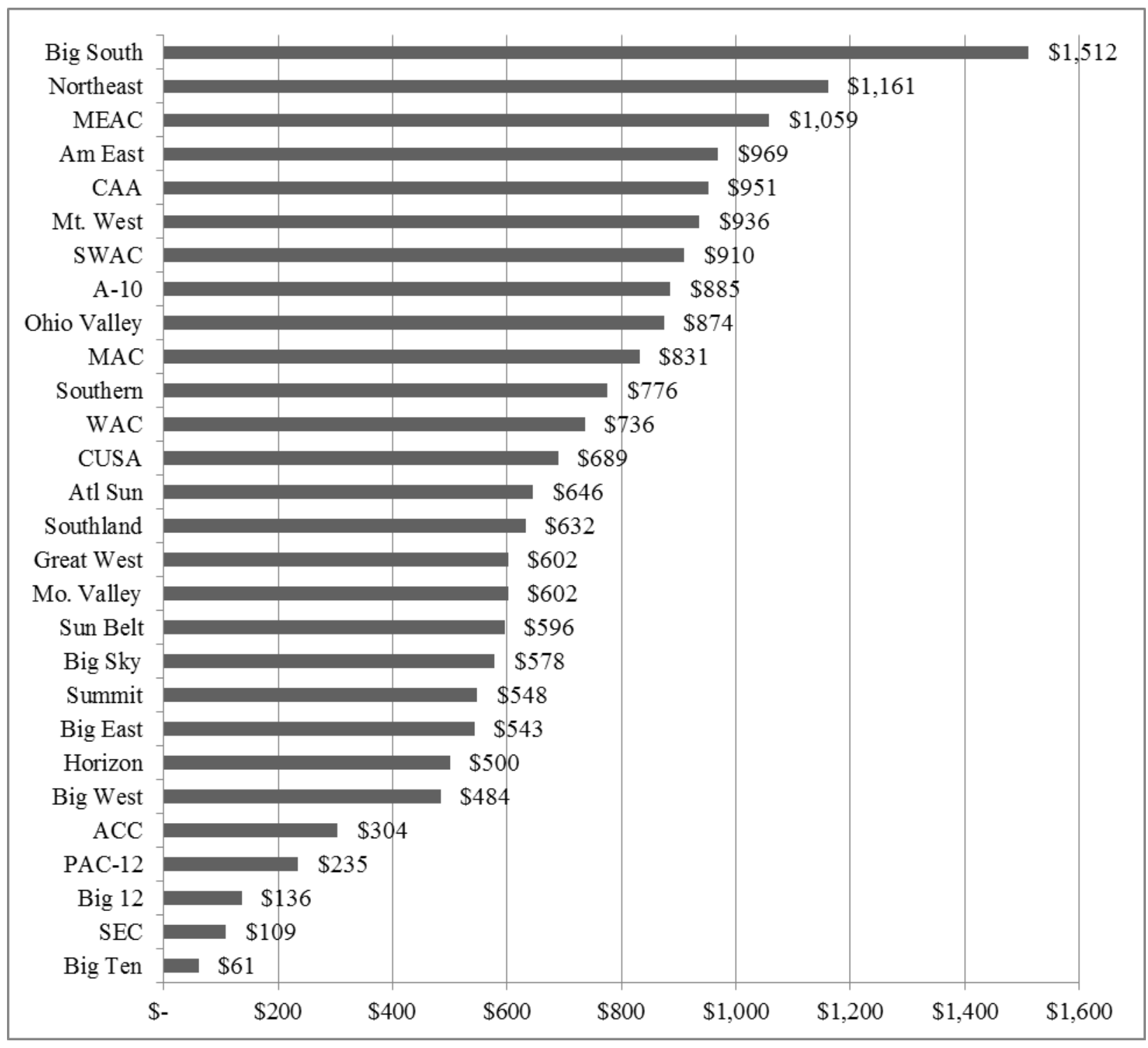

Theoretical Framework for Study

This study follows the theoretical construct of the Asymmetric Information Theory (Akerlof, 1970). The theory concerns transactional decisions where one party has better information than the other. For this study, the one who has the information has the 
transactional power (institution) and the purchaser (student) pays a fee to the institution without typically knowing the full amount of the general fee. In addition the purchaser does not know how the fee is spent and also lacks the choice of whether to pay the fee, or at the very least opt out of certain things the fees pay for. While previous studies have made it clear that explanations for spending in intercollegiate athletics, including charging fees to subsidize athletics, are needed and desired by involved stakeholders as demonstrated in the front porch and winner-take-all market theories, a perceived incentive exists to charge these fees as they will ostensibly make the athletics department more competitive, which might lead to gains in enrollment, marketability, etc. (Chapman et al., 2013; Vedder \& Denhart, 2010). Incentives also exist not to make fees transparent or obvious to the consumer so as to keep the money flowing. This study analyzes the perceptions and knowledge (or lack thereof) of those fees by the primary stakeholders and largest athletic donors in the MAC: the students. The Asymmetric Information Theory provides a foundation for this study in that it discusses monetary charges for individuals who are not plainly aware of the charge or the implications while the one with the transactional power is aware.

\section{Preliminary Data}

The researchers conducted a pilot study in 2011, in conjunction with the Center for College Affordability and Productivity (CCAP), as a basis for this proposal to test the content and face validity of the survey instrument using a MAC institution (Ohio University) as a test population. All undergraduate and post-baccalaureate students enrolled on Ohio's main campus during the fall quarter of the 2010-11 academic year were invited to participate. The survey was conducted online, with an email containing the survey's link sent to all 19,843 students enrolled during the 2011-12 academic year. 910 total students responded completely to the survey and answered all of the questions (Chapman et al., Denhart \& Ridpath, 2011; 2014; Rate \& Karr, 2011, "Students speak out," 2010).

The findings provided an impetus for a more-detailed study such as this. In the pilot study, a higher percentage of Ohio University students (84.1\%) were aware they paid an overall general fee that included intercollegiate athletics subsidies. Many respondents while understanding there was a fee paid toward athletics by each enrolled student, most (85.2\%) were not aware of the amount of the total fee, suggesting a possible lack of transparency or explanation of the full amount of the subsidy. In rating the importance of intercollegiate athletics as to where students wanted their money allocated, athletics was rated consistently lower than its actual funding level and led the researchers to question the large subsidy if fee-paying students do not rate it as valuable as administrators/proponents/athletics boosters advertised (Chapman et al., 2014). 


\section{Demographics}

\section{Methods}

One such NCAA Division I athletic conference with increasing and high institutional subsidies for athletics, including student fees, is the Mid-American Conference, headquartered in Cleveland, Ohio. According to the data presented in Table 3 , the MAC is currently one of the highest subsidized conferences in NCAA Division I with regard to institutional subsidies and student fees (Table 3). Mid-major conferences such as the MAC find themselves trying to compete with institutions in NCAA Division I that have more resources and commercial funding. In the effort to keep up in the winnertake-all market, schools consistently charge students hefty subsidies to finance athletic departments that otherwise could not sustain themselves. In the MAC there are 13 member institutions split into an Eastern and Western division with a total student enrollment of more than 275,000, including more than 5,200 athletes in 23 sports (Table 4). Mid-American Conference institutions are considered peers athletically due to competitive equity, number of sports sponsored, athletic budgets, academic profile of prospective college athletes, and many other areas, such as demographics and size of institution (Ridpath, 2002).

The data demonstrate that the MAC and the Mountain West Conference (MWC) are the most highly subsidized athletic conferences through student fees for athletic programs in the 11 conferences of the BCS (Table 1). The MAC had 9 institutions in the top 25 highest recipients of student fees for athletics among all NCAA Division I BCS schools in 2009-10. (Chapman et al., 2014; “Chart,” 2010).

\section{Research Questions}

The questionnaire presented five specific research questions for analysis: RQ1. Is the student aware that he/she is paying general fees, including an athletic fee? $\mathrm{Y} / \mathrm{N}$

RQ2. Is the student aware of the actual total amount of student fees at their institution? $\mathrm{Y} / \mathrm{N}$

RQ3. Does the student want to pay as much as they are paying for the general fee, specifically for athletics? Y/N

RQ4. Where does athletics rank on their priority list for general fee allocations? Y/N RQ5. Do the students agree with the alignment of university allocations of general fee dollars with student desires, such as influencing school choice? Y/N

For this study, the researchers obtained data from students (undergraduate, graduate, doctoral, and professional) enrolled during the 2012-13 academic year at 12 of the 13 schools in the Mid-American Conference. The challenge of getting data ostensibly defined as public information was difficult and time consuming. One institution consistently refused Freedom of Information Act (FOIA) requests and others provided only limited information. The difficulty in obtaining public information from many of the schools cannot be understated and was challenging for the researchers to accurately 
ascertain the amount of the subsidies considering some of the information was not publically available. Many of the institutions were also reluctant to provide exact amounts of their athletic-fee portion of the general fee, or it was challenging to find accurate numbers, specifically for the institutions that embedded the fee in the overall tuition amount. It took several FOIA requests, telephone calls, and separate Institutional Review Board (IRB) certifications (at some schools) to obtain secondary data and population information. Despite these challenges, the researchers feel that there is an adequate surveyed population and accurate numbers to conduct the study were obtained even though institutional response rates varied widely (Table 4). Limitations and suggestions for combating these issues are discussed in the limitations and suggestions for future research sections. Overall six institutions provided full directory information of all students, four provided smaller proportional stratified samples, two provided names only, and one institution refused to participate (Table 4).

\section{Data Collection}

Data collection was contracted with an independent data collection company, Harris Interactive Research Bureau, which conducted survey research via initial email and follow-up phone calls to increase the sample. The follow-up phone calls (1200 total calls, in which 761 responded) helped temper potential self-selection and non-response bias issues that might result by someone taking the survey to influence their point of view rather than to answer honestly (Phellas, Bloch, \& Seale, 2012). There were several email reminders, along with the telephonic follow up, and a lengthy response time for the surveyed groups. The follow up phone calls were a non-response follow up and revealed similar answers as the survey between and among groups. In addition, the final breakdown of respondents closely resembles the demographic make-up of the institutions. Of the respondents over $80 \%$ represented the typical age of undergraduates (17-24 years of age), mirroring the undergraduate and post-undergraduate populations of the respective campuses for a representative sample across gender, class year, and ethnicity. This particular subgroup represents the largest population on all of the campuses in the study and the group most likely to go to one or more athletic event per year based on responses in the questionnaire. There was no filter to prevent currently enrolled intercollegiate athletes from participating in the survey. That was by design as the researchers wanted an accurate cross-section of university students, including athletes.

Data collection was conducted in four phases:

Phase I Summer-Fall 2012: Compile randomly selected stratified proportional sample, and/or adequate purposive sample of students at MAC institutions using publically available directory information obtained through public-records requests and internet research.

Phase II Late Fall-Early Winter 2012-13: Targeted emails sent to selected population encouraging them to participate in study. 
Phase III February-March 2013: Second round of email surveys sent to those who did not respond to survey request. Provide more incentives if applicable.

Phase IV March-June 2013: Telephonic contact attempted with a sample of those who did not complete survey to encourage survey completion and reduce nonresponse bias.

The instrument used in this study was a self-developed questionnaire, gleaned from and similar to the one used in the pilot study to maximize reliability, with questions regarding institutional subsidies to intercollegiate athletics based on existing literature and empirical data. The specific issues covered in the survey were constructed to obtain the best answers to the research questions. Several questions contained a Likert scale and also asked numerous exploratory and descriptive items such as gender, ethnicity, and year in college. To minimize issues of content validity, the self-reported survey instrument was developed through an extensive review of past and present literature, surveys, and questionnaires, and trial-tested through the pilot test of a like population to strengthen internal validity and consistency (Chapman, et al, 2014; Denhart \& Ridpath, 2011; Johnson \& Christensen, 2000).

The overall response rate to this study, using the revised numbers (Table 4) was $n=3282$ respondents out of $N=110,670$ including Akron and Buffalo. For the data analysis, the final numbers were $N_{1}=109,821$ and $n_{1}=3258$, excluding Akron and Buffalo for a final response rate of $3 \%$ using purposive sampling and stratified proportional samples, depending on the institution. While under the initial goal of 5000 responses, the researchers strongly feel that the sample was representative and adequate based upon using the purposive sampling technique of Proportionate Distribution combined with the Equal Probability Selection Method giving everyone who received the survey an equal chance of answering (Johnson \& Christensen, 2000). The researchers decided to stop the questioning and follow-up phone calls when a proportionate sample of MAC university demographics (such as Gender, Ethnicity and Grade Level) was reached. While the overall response rate was lower than planned, a 3\% response rate at a $95 \%$ CI with a $=/-5 \%$ margin of error, meets criteria where smaller sample sizes are acceptable (Groves, 2006). While it is the goal of all research to generate the largest amount of responses possible, some recent research suggest that that changes in nonresponse rates do not necessarily alter survey estimates (Groves, 2006). Some notable on-line research services, such as Snap Research and Survey Monkey accept less than 700 total completed surveys for a random population of 200,000 (Snap Research, 2013). While $10 \%-80 \%$ is generally considered to be an effective response rate for a researchbased survey, it is still arbitrary and there is no agreed-upon standard of what constitutes an acceptable response rate. It depends on the study itself, the population, and how the survey was conducted (Cummings, Savitz \& Konrad, 2001). 
Table 4

Athletic fee, Surveyed Population and Responses. Excludes part time students

\begin{tabular}{llll}
\hline School & Athletic Fee & Population & Responses \\
\hline & Sem/Year & & \\
University of Akron & $\$ 327 / \$ 654$ & 312 & 16 \\
Ball State University & $\$ 204 / \$ 408$ & 17052 & 254 \\
Bowling Green State & $\$ 352 / \$ 703$ & 14224 & 301 \\
University & $\$ 237 / \$ 474$ & 537 & 8 \\
University of Buffalo & $\$ 309 / \$ 618$ & 5000 & 127 \\
Central Michigan University & $\$ 305 / \$ 609$ & 5000 & 138 \\
Eastern Michigan University & $\$ 271 / \$ 541$ & 5000 & 683 \\
Kent State University & $\$ 453 / \$ 906$ & 4000 & 87 \\
Miami University & $\$ 253 / \$ 506$ & 14494 & 228 \\
Northern Illinois University & $\$ 201 / \$ 401$ & 12353 & 635 \\
Ohio University & $\$ 300 / \$ 600$ & 11759 & 368 \\
University of Toledo & $\$ 331 / \$ 663$ & $\mathrm{~N} / \mathrm{A}$ & $\mathrm{N} / \mathrm{A}$ \\
Western Michigan Univ. & $\$ 463 / \$ 925$ & 20939 & 387 \\
University of Massachusetts & \multicolumn{2}{c}{$N=110,670$} & $n=3282$ \\
& \multicolumn{2}{c}{$N_{1}=109,821$} & $n_{1}=3258$
\end{tabular}

\section{Data Analysis}

This research was designed as a descriptive research design, mixed-methods study, with quantitative and qualitative data that enables the researchers to perform a deeper analysis of the findings provided by the respondents' answers. This proposal incorporated self-reported data gleaned from the survey instrument of a purposive proportional sample of students who attended MAC schools during the 2012-13 academic year. The population was selected according to the steps mentioned in the data-collection section.

\section{Descriptive Statistics}

One objective of this study was to glean a sample of up to 5,000 enrolled students at MAC institutions during the 2012-13 academic year at all academic levels who were fee-paying students (undergraduate, masters, doctoral, and distance learning). Another objective was to ensure a good cross-section of the population proportionate 
demographically to limit potential bias of any one group such as graduate, doctoral, or distance-learning students who might pay fees, but likely have a lesser interest in the university sports program than undergraduates which was validated by answers given on the questionnaire (Denhart \& Ridpath, 2011).

Of the respondents, $60 \%$ were female and $39 \%$ were male. This is slightly higher than the overall male/female ratio in MAC institutions, but valid for the purposes of the study. The ages of the respondents varied from $18-65+$, but $89 \%$ of those responding were in the 17-29 age group, a key demographic more likely to watch sporting events (Milner \& McDonald, 1999). This proportion is almost exact with the enrollment breakdown by age at MAC institutions which have primarily traditional college aged students attending (18-22 years of age). With regard to ethnicity, 84\% identified as Caucasian/White, while the remaining percentage identified as non-white (AfricanAmerican, Latino, or other). This also resembles the overall ethnic breakdown of MAC schools. The majority of the respondents were undergraduates (75\%), and 25\% identified as master's or doctoral students. The bulk of the population also fell within the 2.5-4.0 GPA range, which matches well with the overall average GPAs of students at MAC institutions.

To add to the validity of the study, the researchers performed some data cleansing and eliminated the responses from the Universities of Buffalo and Akron due to their low institutional response rates (Table 4). The researchers also eliminated part-time students for the data analysis because they typically pay much lower pro-rated general fees including the athletic subsidy and the amount part-time students paid in fees varied substantially by institution. The final analysis numbers kept the response rate fairly consistent, but more accurate by using only full-time degree-seeking students paying the full general and athletic fees at their respective institutions. Considering the population of currently enrolled college students at MAC institutions, the researchers are confident in the adequacy and representation for the purposes and goals of this study.

\section{Research Questions 1-3}

\section{Results}

The researchers employed $t$-tests, excluding part-time students and respondents from Akron and Buffalo, to analyze the research questions by comparison of conditional means. For Research Questions 1, 2, and 3, the analysis was done both separately for the full revised sample. Subsequent analysis eliminated full-time graduate and doctoral students for a robustness check to insure the results were consistent. The other questions were analyzed using the entire revised sample excluding Akron, Buffalo, and part-time students.

The first test statistic was defined from how students responded to the question, "To your knowledge, does your university charge a general fee (in addition to tuition and room/board charges)?” They had the options “yes," "no," and "I don’t know.” Those who 
answered "yes" were given a value of 1 , while those who were unsure were given a zero to create the variable of interest $\left(\operatorname{var} 1_{\mathrm{i}}\right)$. The test statistic $\left(\mathrm{x}_{1}\right)$ was calculated by $x_{1}=$ $\frac{\sum v \operatorname{var} 1_{i}}{n}$ and was tested for significance in Table 5 with a one-tailed t-test against the following hypothesis:

$\mathrm{H}_{0}$ : Students all know that they are charged a student fee ( $\left.\mathrm{x}=100 \%\right)$.

$\mathrm{H}_{\mathrm{A}}$ : Students do not all know that they are charged a student fee $(\mathrm{x}<100 \%)$.

The second test statistic was defined by the difference between student responses when asked to estimate their fees ( $\left.\mathrm{est}_{\mathrm{i}}\right)$ and the actual fees for their respective school (act $\mathrm{i}_{\mathrm{i}}$. The test statistic $\left(\mathrm{x}_{2}\right)$ was calculated by $x_{2}=\frac{\sum e s t_{i}-\text { act }_{i}}{n}$ to capture the average error of the estimation. $\mathrm{x}_{2}$ is tested for significance in Table 5 with a two-tailed t-test on the following hypothesis:

$\mathrm{H}_{0}$ : Student estimates of the fee are equal to the actual fee $(\mathrm{x}=0)$.

$\mathrm{H}_{\mathrm{A}}$ : Student estimates of the fee are not equal to the actual fee $(\mathrm{x} \neq 0)$.

The third test statistic was defined from how students responded to the question, "Please select a range that you would be willing to pay per year to support the intercollegiate athletics department maintaining its current Division 1 status in the (MAC) of the National Collegiate Athletic Association (NCAA).” They had the options to decrease, to keep the fee the same in the future, or to increase the fee by several different amounts per semester. These answers are shown more fully in Table 6 . Those who answered that they wanted the fee to decrease in the future were given a value of 1 , while those who did not were given a zero to create the variable of interest (var2 $\left.2_{\mathrm{i}}\right)$. The test statistic $\left(\mathrm{x}_{3}\right)$ was calculated by $x_{3}=\frac{\sum v a r 2_{i}}{n}$ and was tested for significance in Table 5 below with a one-tailed t-test against the following hypothesis:

$\mathrm{H}_{0}$ : Students are content with the fee and do not want to reduce the fee ( $\left.\mathrm{x}=0 \%\right)$. $\mathrm{H}_{\mathrm{A}}$ : Students are not content with the fee $(x>0 \%)$. 
Table 5

Research Questions 1, 2 \& 3 Comparison by Conditional Means

\begin{tabular}{|c|c|c|c|c|c|c|c|c|}
\hline & \multicolumn{4}{|c|}{ Full Revised Sample } & \multicolumn{4}{|c|}{ Without Graduate Students } \\
\hline & Mean & t statistic & $\mathrm{p}$ value & & Mean & t statistic & $\mathrm{p}$ value & \\
\hline RQ1: & $\begin{array}{r}37.30 \% \\
(0.0095)\end{array}$ & 39.07 & $<.001$ & $* * *$ & $\begin{array}{r}40.90 \% \\
(0.0104)\end{array}$ & 39.27 & $<.0001$ & $* * *$ \\
\hline RQ2: & $\begin{array}{r}-\$ 95.00 \\
(11.10)\end{array}$ & -8.56 & $<.001$ & $* * *$ & $\begin{array}{r}-\$ 103.32 \\
(12.14)\end{array}$ & -8.51 & $<.0001$ & $* * *$ \\
\hline RQ3: & $\begin{array}{r}48.20 \% \\
(0.0099)\end{array}$ & 48.86 & $<.001$ & $* * *$ & $\begin{array}{r}46.90 \% \\
(0.0106)\end{array}$ & 44.37 & $<.0001$ & $* * *$ \\
\hline
\end{tabular}

Standard Errors are reported in parentheses below

statistics

Table 6

Do students want to pay as much as they are paying to finance the athletic department?

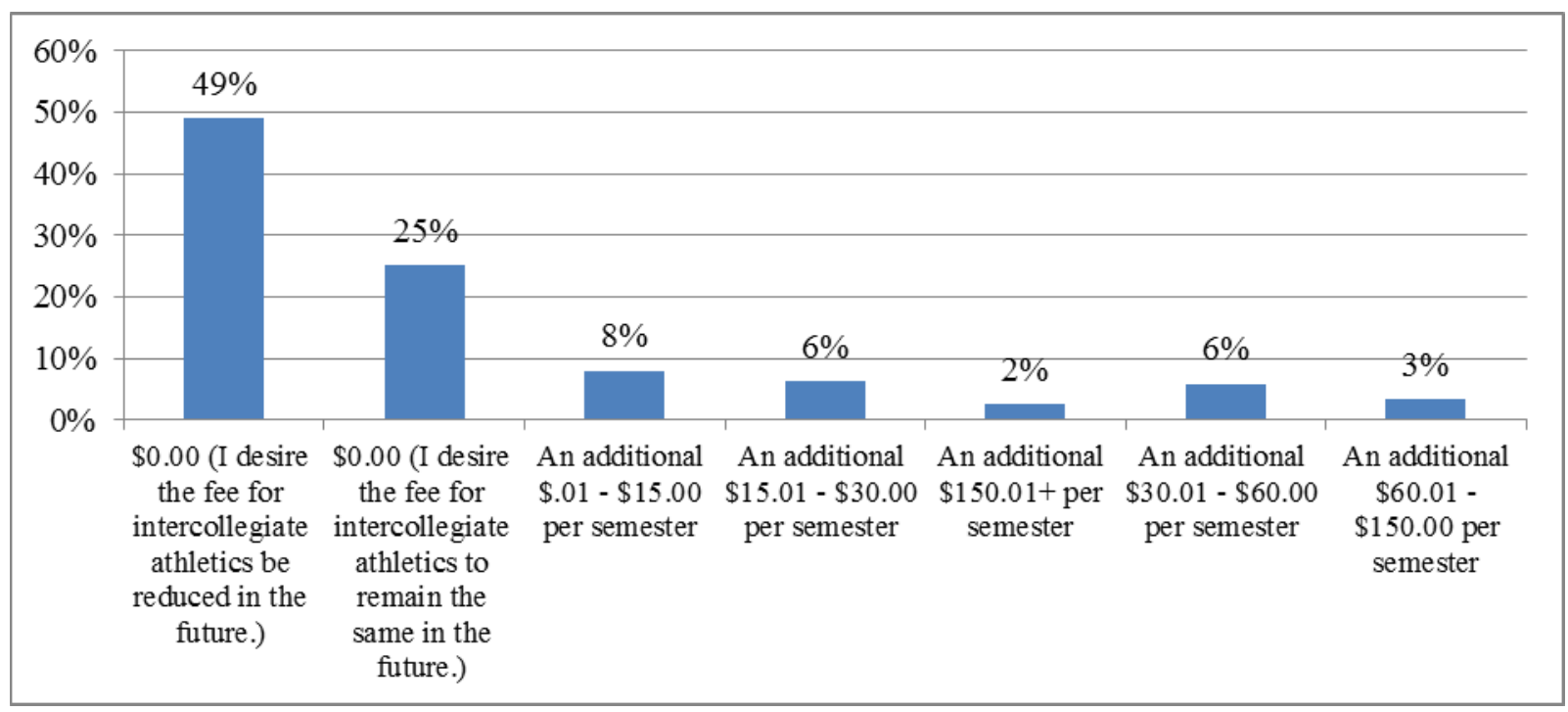


One of the more consistent claims by university presidents, certain alumni, and athletic administrators and coaches is that having a successful athletic program is a priority of the student body and funding it to a competitive level is important. In addition athletics is often touted as a strong and positive enrollment driver, along with it being a significant reason for a prospective student in choosing a college or university to attend. (Chapman, et al, 2014; Rate \& Karr, 2011; Vedder \& Denhart, 2010). The data presented in Tables $7 \& 8$ contradict that line of thinking, at least in the Mid-American Conference. Since it is one of the highest subsidized athletic conferences it is important to glean the data from the student body to ascertain if indeed it is as important as often claimed.

Table 7

Where does Intercollegiate Athletics rank as a priority for funding and was it important in school choice? (RQ 4)

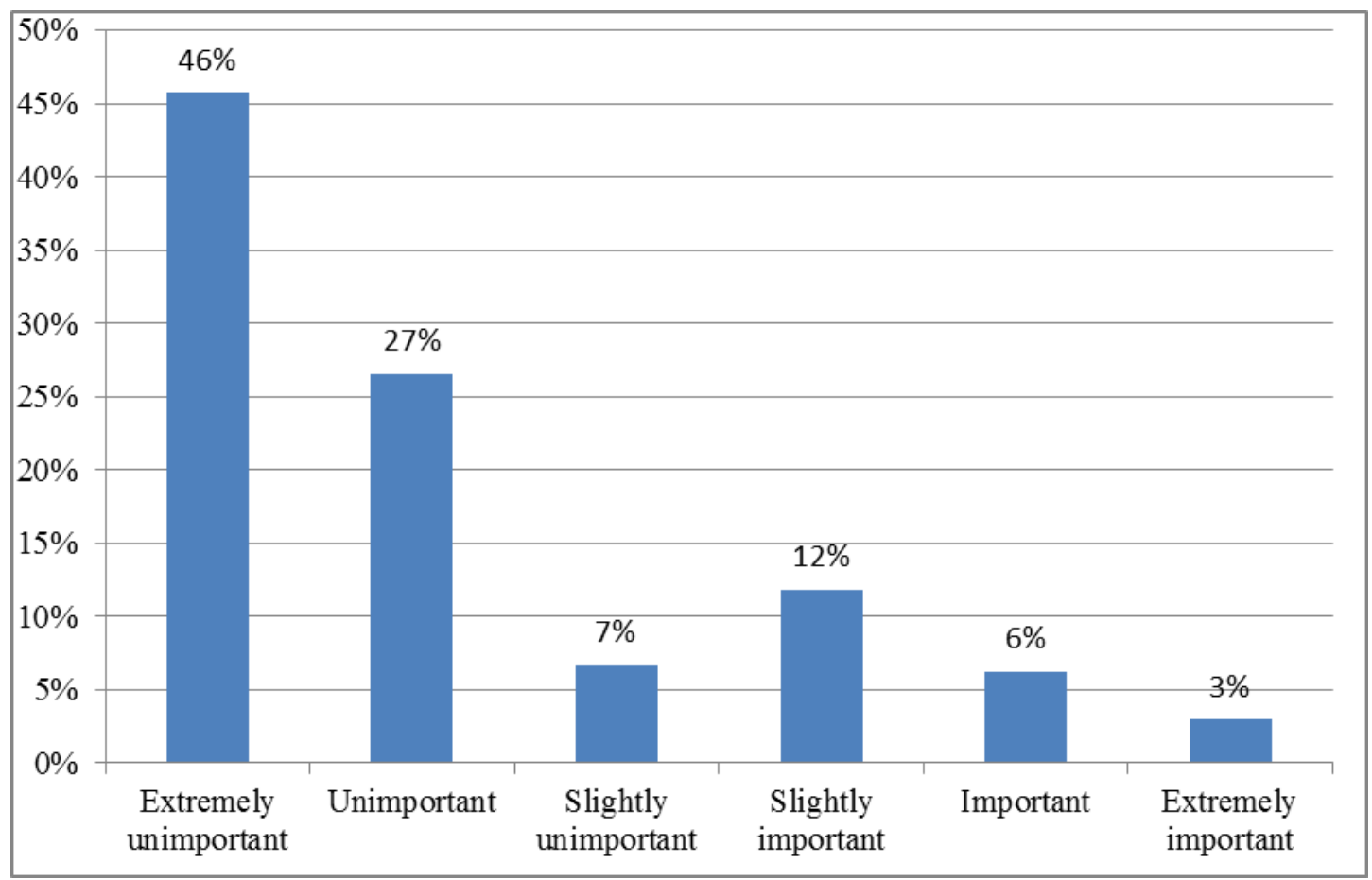


Table 8

Ranking the 8 Most Commonly Funded Areas of Student Fee Allocations (RQ 5)

Personal Importance vs. Perceived University

Importance Ranks 1-8 (Undergraduate)

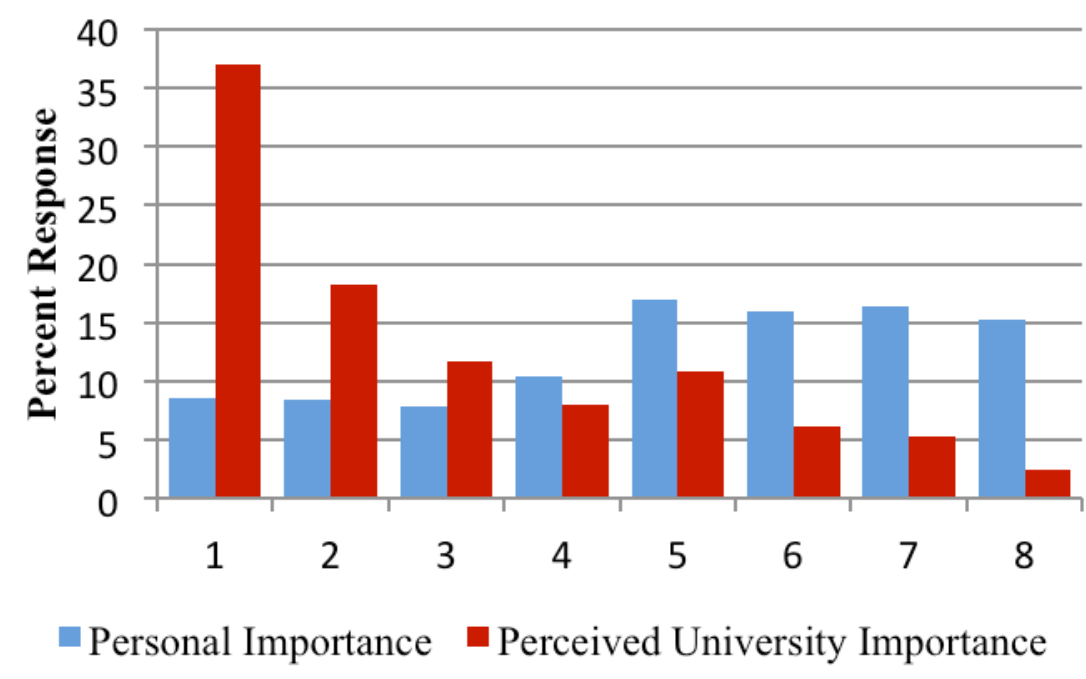

\section{Qualitative Responses}

At the end of the survey, the students were given an opportunity to make additional comments on the topic of athletic fees. The qualitative statements mirrored the quantitative responses in most cases. Almost 700 students responded to the last question, and specific comments are below. These responses were varied and at many times pointed, but the themes that consistently came across in the qualitative answers, like the quantitative responses, mostly indicated a lack of knowledge, disappointment, or outright anger over the charging of the fees. A low percentage (less than 5\%) of qualitative responses supported the continuation of athletic fee assessments at the current amounts or even supported increase fee assessments in the MAC.

While many qualitative answers were similar to the quantitative ones, the overriding theme of the qualitative responses was a desire to have an itemized bill so that the students/parents would know how universities spent the money. The amounts going to specific athletic programs was surprising to many, but even in cases like this several respondents still expressed a desire to continue paying fees to athletics because they felt it was good for the entire school and they enjoyed sports, but not at the amounts that were provided in the survey. Again, the majority of the respondents did not know the university assessed an athletic fee in addition to tuition. Some sample qualitative 
statements that supported the themes above and are representative of over $90 \%$ of the answers given include:

1. "Thank you for bringing this to my attention. I really appreciate this."

2. "Knowing multiple athletes, I still think we have to pay too much for the athletic program."

3. "Before this survey I knew there was a general fee, but I had no idea how much."

4. "In order to continue the fine level of athletics in the Mid-American Conference it is essential to continue to ask for the support of the student body. Otherwise the larger more profitable conferences will continue to dominate with their excess of funds."

5. Absolutely ridiculous! I had no idea this was going on. I will definitely look into this. I have never been to a sporting event here, nor do I ever plan to.

6. "I didn't even know there was a general fee. This survey actually shocked me and I was just so surprised because I feel like that is a lot of extra money per year. I can barely afford college as is and finding out that I have to pay about $\$ 1,500$ dollars more just for some of the stuff mentioned in the survey it made me mad. I can't get help to pay for school because my school doesn't have it yet I have a little over $\$ 1500$ due and it could be because of that general fee. Are you serious??? That could be the reason that I can't afford to go here. That is some bull crap."

7. "Students should have a greater input into how their general fee contribution is used."

8. "I would appreciate knowing exactly what my general fee was going towards and exactly how much."

9. "The general fee should be itemized to give students a better understanding of what they are paying for. College is expensive and it's important to know where our money is going and if it is relevant to us."

10. "I understand that athletics are important to some, but I feel that a learning institution such as a college should focus on academics and the teaching/learning experience. I would prefer to go to a college that has a Division 1-type status in some sort of knowledge-based competition. The athletics can still be a maintained part of the school, but I feel as if it is 
supported and advertised over the educational accomplishments the school should be striving for first and foremost."

\section{Conclusions and Recommendations}

The quantitative and qualitative data demonstrate that a sizable number of students remain unaware that they pay an overall general fee, much less a specific athletic fee. The ones aware of the fee were unaware of the amount. That disconnect can exist for several reasons: the students themselves do not pay the bill, expenses can be largely covered by grants, loans, and scholarships, and the fact that most institutions in the MAC lack transparency with their fees, often only listing a total general fee amount and not itemizing the actual amounts, specifically the amounts for athletics ("Examining the University Bill,” 2011). In most cases, it is very difficult to find the exact amounts charged in the general fee and even more difficult to find out the exact amount of the general fee that goes toward athletics. While this information is publically available in all cases for MAC institutions, it is a difficult exercise to find exact numbers through university records (“Examining the University Bill,” 2011; Ridpath et al., 2013). In the case of the MAC and similar institutions that do not generate enough revenue to cover costs, the athletic programs almost entirely depend on financial support from students. The lack of transparency and ignorance surrounding fees by students as the primary consumer challenge the theory that funding at the highest possible level increases competitive equity and tis important to the overall good of the institution (Tucker, 2011).

At the very least, a primary recommendation for institutions in the MAC is to be transparent about their fee structure, including the exact amount that goes for athletics. Let the student/parent decide if they want to pay it by enrolling or not enrolling, but do not hide it or make it seem like a backdoor tuition increase. Deception makes it appear as if the university prefers the public to be ignorant. That may not reflect reality, but it is a realistic perception considering the difficulty in finding exact numbers. This aligns with the theoretical construct of Asymmetric Information in that the student consumers as purchasers do not have the information to make informed decisions. The institutions with transactional power often do not give the full information of the fees and what they are used for, specifically for spending in intercollegiate athletics. Affordability and access to a high-quality postsecondary education is critical in the 21st century for workforce development, economic output, and individual career success. However, while tuition, fees, and room and board at four-year residential institutions continue to increase, many students turn to more affordable two-year institutions. By 2009, almost half of all college students at public institutions attended a two-year campus and this trend is continuing at roughly 45\% in 2012-13 (American Association of Community Colleges, 2014; DeilAmen, 2011; Vedder \& Denhart, 2010). An economic theory called the Teibout Hypothesis supports the trend toward lower cost educational options and is a contrast to the Asymmetric Information Theory in that it supports that information received on perceived higher costs may actually cause a reverse effect on enrollment, even if an 
institution has high levels of athletic success. The hypothesis, developed by Charles Teibout, explains why people would switch voting districts because of economic benefits, real or perceived, in the other district. In essence, the Tiebout hypothesis formalizes voting with the feet or casting a vote for the jurisdiction with the most preferred package of government activity. If one district has higher taxes than another with lower taxes that encourage business activity, a citizen can essentially cast a vote for the most compatible district by moving there (Wooders, 1999). Continued growth in intercollegiate athletic expenses, mostly through increased student athletic fees can lead to the consumer choosing the lower educational cost option and have the opposite effect desired by the institutions who are charging the fee.

While institutions believe that this primary funding mechanism for intercollegiate athletic programs is needed and desired by involved stakeholders, it is clear at least in the MAC as demonstrated in the front porch and winner-take-all market theories, a perceived incentive exists to charge these fees. The belief is this subsidy might make the "front porch" more appealing through athletic success and lead to gains in enrollment, marketability, fund raising and academic status. There appears to be an incentive not to make fees transparent or obvious to the consumer because as the data demonstrate, most students do not know about the fee and do not want to pay it. While the fee paying student would desire this information, colleges and universities are theoretically more incentivized to keep tuition down and transparent while many hidden costs are within the general fee amount. Colleges and universities should understand the real possibility that fee-paying students and their parents will look at other, more optimal and market-like educational options should athletic fees become too burdensome, at least at some schools as in this data set, where athletics do not drive college choice.

If institutions want to justify the amount of student fees going toward athletics department operations, institutions need to do a much better job of showing the benefits of an athletics department and increasing institutional subsidies for it. The schools can do that by providing empirical data (if it exists) and long-term benefits of athletics to the student population, academic programs, and alumni, and not continue to recite empirically unsupported statements like the Front Porch Theory. Repeating a belief opinion does not make it fact if unsupported by data. If tangible gains and benefits exist, universities should be able to document and show those beyond unsustainable short-term positive spikes.

\section{Limitations of Study}

Several limitations in this study must be discussed. While it was disappointing not to get full cooperation from all 13 schools of the MAC, it did not limit the data findings but did limit the ability to get a larger participation sample. In the areas where the researchers had to find personal student data themselves by online data mining, the response rate was very low, causing those schools (Akron and Buffalo) to be excluded from the final data analysis. It cannot be said for certain that, if Western Michigan 
participated and if Akron and Buffalo provided directory information, the results would be the same. The data might support the trends that have been presented, or it might change the results enough to alter the conclusions. Based upon the trends and the minimal information provided by Buffalo and Akron, including the confidence interval of the current analysis, the researchers believe those exclusions would not alter the findings of the study based on the diversity of the population, answers given, and the confidence interval of the data analysis.

Getting the exact amount of fees paid by each student, specifically the athletic fee was also challenging. Some universities in this study were reluctant to share-or, at least, share easily - that information while others were very cooperative. It is not for certain whether the athletic fees reported for this study are $100 \%$ accurate, as many times the exact subsidy can be a moving target. One university (Toledo) could not provide an exact amount, only an estimate, based on the trend of calculating at the end of the fiscal year what students will pay for their athletic subsidy and other student fees based upon total amount of general fee revenues collected at the end of a fiscal year.

\section{Recommendations for Further Research}

Excluding part-time students from the final analysis was a decision of the research team because they are not paying the full amount of the fee. In the future, it might be interesting to analyze the perceptions of part-time students to gauge their assessment of fees they pay, including the athletic fee, regardless of the percentage difference. The researchers plan to expand this study regionally and nationally in the future while enhancing and expanding the qualitative aspect to gather more direct and detailed responses, in addition to enhancing the survey instrument. There simply needs to be a greater awareness of the issue to all constituents involved in higher education, and an expanded study will assist in that goal.

The influence of new media on intercollegiate athletics also cannot be discounted. It can be argued that athletics had a greater influence on school choice before the proliferation of college games, in every conceivable sport, being readily available on television, computers, and handheld electronic devices. Consequently, it can be hypothesized that many consumers, including students attending mid-major schools like those in the MAC, no longer have the attraction to their own institution's athletic programs because of the availability for constant contact with larger, more popular intercollegiate programs in the state or region. That could significantly affect the viability of mid-major programs in that they lose fans and other revenue streams to institutions that have financially viability, thus creating a situation where more institutional subsidies are needed for the winner-take-all market.

Any future study must involve some level of compensated legal counsel for public-information extraction from public institutions to free up researchers for data analysis. A tremendous amount of time was spent on filing FOIA requests, responding to answers and inquiries. Additionally, future researchers should involve elected officials 
and their local offices to accelerate public-information access so that all students at public institutions, along with parents and funding agencies, can have the opportunity to know how much their institutions charge for the total general fee, including the amount that goes towards athletics. 


\section{References}

2011-12 Comprehensive Fee Report-Athletic Fee (n.d.). The University of Buffalo Office of Student Accounts: Tuition \& Fees. Retrieved from http://studentaccounts.buffalo.edu/tuition/compfee/athletics.php

Akerlof, G. (1970). The market for lemons: Quality uncertainty and the market mechanism. The Quarterly Journal of Economics. 84(3), pp. 488-500.

American Association of Community College (2014). 2014 fact sheet. Retrieved from http://www.aacc.nche.edu/AboutCC/Documents/Facts14_Data_R3.pdf

Bergerson, A. (2009). College choice as a comprehensive process. ASHE Higher Education Report, 34(4), 21-46.

Berkowitz, S. (2013, June 19). A proposal for better balance sheets among NCAA members. USA Today. Retrieved from http://www.usatoday.com/story/sports/college/2013/06/18/ncaa-athletic-subsidiesaccounting-changes/2435527/

Berkowitz, S., Upton, J., McCarthy, M. \& Gillum, J. (2010, October 6). How students fees boost college sports amid rising budgets. USA Today. Retrieved from http://www.usatoday.com/sports/college/2010-09-21-student-fees-boost-collegesports_N.htm\#uslPageReturn

Berkowitz, S., Upton, J. \& Brady, E. (2013). Most NCAA Division I athletic departments take subsidies. USA Today. Retrieved from http://www.usatoday.com/story/sports/college/2013/05/07/ncaa-financessubsidies/2142443/

Chapman, M., Ridpath, B., \& Denhart, M. (2014). An examination of increased NCAA Division I athletic department budgets: A case study of student perceptions of fee allocations for athletics. International Journal of Sport Management. 15(1), pp. 124.

Chart: analyzing the percentage of tuition that goes to athletics. (2010, September 21). USA Today, Retrieved from http://www.usatoday.com/sports/college/2010-09-21athletic-fees-chart_N.htm\#uslPageReturn.

Cummings, S., Savitz, L., \& Konrad, T. (2001, February). Reported response rates to mailed physician questionnaires. Health Services Research. 35(6), pp. 1347-1355.

Deil-Amen, R. (2011, November). The "traditional” college student: A smaller and smaller minority and its implications for diversity and access institutions. Symposium conducted at the Mapping Broad Access Higher Education Conference, Palo Alto, CA.

Denhart, M., \& Ridpath, B. (2011). Funding the arms race: A case study of student athletic fees. Center for Collegiate Affordability and Productivity, Washington, DC. Retrieved from: http://www.centerforcollegeaffordability.org/uploads/Funding_the_Arms_Race.p df 
Kent State University School of Journalism and Mass Communication (2011). Examining the university bill. Retrieved from http://et.kent.edu/jmc40004/fees/

Frank, R. (2004). Challenging the myth: A review of the links among college athletic success, student quality, and donations. Retrieved from: http://www.knightcommission.org/index.php?option=com_content\&view=article \&id=73\&Itemid $=4$

Frank, R. \& Cook, P. (1995). The winner-take-all society: Why the few at the top get so much more than the rest of us. New York: Simon \& Shuster.

McGranahan, E. (2014, 13 November). Clemson ponders athletics fees for students. The Columbia State Journal. Retrieved from http://www.thestate.com/2014/11/11/3806076/clemson-ponders-athleticsfees.html

Groves, R. (2006). Non-response rates and non-response bias in household surveys. Public Opinion Quarterly. (70)5, pp. 646-675. doi: 10.1093/poq/nfl033

Jaschik, S. (2007). Scrutiny for student fees. Inside Higher Ed. Retrieved from: Journal\%20of\%20Sport\%20Review\%20Ridpath.dochttp://www.insidehighered.c om/news/2007/11/21/fees

Johnson, B. \& Christensen, L. (2000). Educational research: Quantitative and qualitative approaches. Boston: Allyn and Bacon.

Litan, R., Orszag, J. \& Orszag, P. (2003, August). The Empirical Effects of Collegiate Athletics: An Interim Report: Washington, DC: Sebago Associates. Commissioned by the National Collegiate Athletic Association.

Lorence, J. (2003). Fire's guide to student fees, funding, and legal equality on campus. Philadelphia: Foundation for Individual Rights in Education.

McClendon, M., Hearn, J., \& Mokher, C. (2009). Partisans, professionals, and power: the role of political factors in state higher education funding. Journal of Higher Education, 80(6), 686 - 713. doi: 10.1353/jhe.0.0075

Meabon, D., Alexander, R., \& Hunter, K. (1979). Student activity fees: A legal and national perspective. Columbia, SC: NECAA.

Millet, J.D. (1969). Memorandum for presidents and directors of state-assisted institutions of higher learning. Columbus, $\mathrm{OH}$.

Milner, G., \& MacDonald, M. (1999). Sport marketing: Managing the exchange process. Sudbury, MA: Jones \& Barlett.

National Center for Post-Secondary Improvement (NCPSI), US Department of Education (1998). The transition from initial education to working life in the United States of America. Retrieved from http://www.oecd.org/edu/innovationeducation/1908306.pdf

Ott, K. (2009). Students' awareness and perceptions of the activity fee at the University of Toledo: a descriptive research study. Department of Education, University of Toledo, Toledo, OH. Retrieved from: http://etd.ohiolink.edu/sendpdf.cgi/Ott\%20Katherine\%20S.pdf?toledo1239728340 
Page, C. (2011, May 31). Make college worth the cost. Middletown Journal. Retrieved from www.middletownjournal.com/opinion/columnists/clarence-page

Phellas, C., Bloch, A., \& Seale, C. (2012) Structured methods: Interviews, questionnaires, and observation. In Seale C. (Ed.) Researching society and culture, $3^{\text {rd }}$ Edition (pp. 182-202). London: SAGE Publishing.

Rate, B \& Karr, R. (2011, March 4). Sis, Boom, Bust: The high cost of college sports [Television Series Episode]. In E. Goldberg (Editor), PBS: Need to Know. New York, NY: Public Broadcasting System.

Ridpath, B. (2002). NCAA Division I student-athlete characteristics and indicators of academic achievement and graduation from college. (Doctoral dissertation, West Virginia University). Available from ProQuest Dissertations and Theses database. (UMI No. 3055939.

Rudolph, F. (1962). The American college and university: A history. New York: Knopf Publications in Education.

Smith, J., \& Caldwell, S. (n.d.) Transparency of athletic fees, subsidies, and appropriations in South Carolina's NCAA Division 1 universities. (Manuscript in Preparation). University of South Carolina-Upstate, Spartanburg, SC.

Students speak out: Students perspective on the Ohio University budget. (2010, February). A Report by the Ohio University Student Senate February 2010.

Suggs, W. (2003). Sports as the university's front porch? The public is skeptical. The Chronicle of Higher Education, 49(34), A17.

Tandberg, D. (2010a). The politics of state funding of public higher education. Educational Policy, 24(5), 735 - 778. doi: 10.1177/0895904809339163

Tandberg, D. (2010b). Politics, interest groups, and state funding of public higher education. Research in Higher Education, 51(5), 416 - 450. doi: 10.1007/s11162010-9164-5

The image of Ohio University: 2006-2007 freshman marketing study (2007, July). Office of Institutional Research: 07-SI-24

Thomas, J.R. (2012, January 27). State's colleges put on notice to stop raising tuition. The ct mirror. Retrieved from http://www.ctmirror.org/story/states-colleges-putnotice-stop-raising-tuition

Tucker, K. (2011, May 29). Details on student's fees not often spelled out. Norfolk Virginian-Pilot. Retrieved from http://hamptonroads.com/2011/05/details-studentfees-not-often-spelled-out

U.S. Department of Education, Institute of Educational Sciences. (2010). Digest of Education Statistics 2009. Washington, DC: Retrieved from: http://nces.ed.gov/programs/digest/d09/index.asp.

Vedder, R., \& Denhart, M. (2010 April). Intercollegiate athletics subsidies: A regressive tax. Center for Collegiate Affordability and Productivity, Washington, DC. Retrieved from 
http://centerforcollegeaffordability.org/uploads/ICA_Subsidies_RegressiveTax.pd $\mathrm{f}$

Weaver, K. (2011, January-February). A game change: Paying for big-time college sports. Change: The Magazine of Higher Learning. Retrieved from www.changemag.org/se/util/display_mod.cfm?

Wooders, M. (1999). Multijurisdictional economics: The Teibout hypothesis and sorting. Proceedings of the National Academy of Sciences of the United States of America. (96)19, pp. 10585-87. doi: 10.1073/pnas.96.19.1058 